\title{
Measurement of Tryptophan in Peptides by Acid Hydrolysis in the Presence of Phenol and its Application to the Amino Acid Sequence of a Sea Anemone Toxin
}

\author{
Koji Muramoto, Satoshi Sunahara and Hisao KamiYa \\ School of Fisheries Sciences, Kitasato University, \\ Sanriku, Iwate 022-01, Japan
}

Received December 15, 1986

\begin{abstract}
The addition of phenol (about $1 \%$ ) to $6 \mathrm{M} \mathrm{HCl} \mathrm{largely} \mathrm{prevented} \mathrm{destruction} \mathrm{of} \mathrm{tryptophan}$ during hydrolysis of peptides at $110^{\circ} \mathrm{C}$ for $22 \mathrm{hr}$. Tryptophan recovery depended on the volume of $6 \mathrm{M} \mathrm{HCl}$ containing phenol and the concentration of phenol. The maximum tryptophan recovery was $85 \%$ for a standard amino acid mixture. The recovery was slightly lower for proteins. This hydrolytic procedure was advantageous for micro amino acid analysis using a conventional highperformance liquid chromatography with a precolumn labeling technique. The method was used in the amino acid sequence analysis of a minor component of sea anemone toxins isolated from Anthopleura fuscoviridis. The toxin consisted of 48 amino acid residues with three tryptophan residues.
\end{abstract}

Tryptophan in peptides and proteins is destroyed during conventional hydrolysis with $6 \mathrm{M} \mathrm{HCl}$ at $110^{\circ} \mathrm{C}$ for $22 \sim 24 \mathrm{hr}$. Various methods for tryptophan measurement have been reported including the addition of thioglycolic acid to $6 \mathrm{M} \mathrm{HCl}^{1,2)}$ and hydrolysis using $p$ toluenesulfonic acid, ${ }^{3)} 4 \mathrm{M}$ methanesulfonic acid containing 0.2\% 3-(2-aminoethyl)-indole ${ }^{4)}$ or $3 \mathrm{M}$ mercaptoethanesulfonic acid ${ }^{5,6)}$ instead of $6 \mathrm{M} \mathrm{HCl}$. Although these methods are successful in total amino acid analysis by ionexchange chromatography on an automatic amino acid analyzer, the nonvolatility of the solvents makes these methods difficult to use in the newly developed micro amino acid analysis using conventional high-performance liquid chromatography (HPLC) with precolumn labeling, ${ }^{7}$ because the $\mathrm{pH}$ of the hydrolysate must be adjusted before derivatization which dilutes the hydrolysate.

In this paper we show that the addition of phenol (about $1 \%, \mathrm{w} / \mathrm{v}$ ) to $6 \mathrm{M} \mathrm{HCl}$ largely prevented the destruction of tryptophan during hydrolysis. The acid solvents were evaporated under a vacuum, therefore, the dried hydrolysate could be directly labeled, keeping the reaction mixture to a minimum volume. This hydrolytic procedure was used on the amino acid sequence of a minor component of sea anemone toxins isolated from Anthopleura fuscoviridis. Recovery of the 1-dimethylaminonaphthalene-5-sulfonyl chloride (DNS-C1) derivative of tryptophan from the acid hydrolysis was also described.

\section{MATERIALS AND METHODS}

Chemicals. Concentrated $\mathrm{HCl}$ (analytical grade), phenol, and a standard amino acid mixture were purchased from Wako Pure Chemicals. Lysozyme (chicken egg white) was obtained from Millipore. 4-Dimethylaminoazobenzene- 4 '-sulfonyl chloride (DABS-C1) was from Dojin Chemical. DNS-C1 was from Pierce Chemical. All other chemicals and solvents used were of analytical grade.

Abbreviations: HPLC, high-performance liquid chromatography; DNS-Cl, 1-dimethylaminonaphthalene-5sulfonyl chloride; DABS-Cl, 4-dimethylaminoazobenzene-4'-sulfonyl chloride; AFT, sea anemone toxin from Anthopleura fuscoviridis; TFA, trifluoroacetic acid; CAM, S-carboxamidomethyl; FITC, fluoresceinisothiocyanate; FTH, fluoresceinthiohydantoin. 
$6 \mathrm{M} \mathrm{HCl}$ containing phenol. Six $\mathrm{M} \mathrm{HCl}$ containing phenol was prepared by double distillation of a mixture of $80 \mathrm{ml}$ of concentrated $\mathrm{HCl}, 80 \mathrm{ml}$ of distilled water, and $1.6 \mathrm{ml}$ of phenol. The constant boiling fraction was taken, divided into screw capped test tubes, and stored at $4^{\circ} \mathrm{C}$. The concentration of phenol in the constant boiling $\mathrm{HCl}$ was estimated to be $0.7 \%$ by ultraviolet absorbance at $290 \mathrm{~nm}$. The $6 \mathrm{M} \mathrm{HCl}$ containing $0.7 \%$ phenol was used in this experiment unless otherwise mentioned. Six $\mathrm{M}$ $\mathrm{HCl}$ containing $2.8 \%$ phenol was prepared by double distillation of $6 \mathrm{M} \mathrm{HCl}$ containing $4 \%$ phenol.

Acid hydrolysis. An acid-washed glass tube with an outer diameter of $5 \mathrm{~mm}$ and an inner diameter of $3 \mathrm{~mm}$ was flamed to form a bottle $50 \sim 60 \mathrm{~mm}$ long. Sample solution was placed in the bottom of the tube and then dried in vacuo. Six $\mathrm{M} \mathrm{HCl}$ was added and the tube was evacuated for $10 \sim 20 \mathrm{sec}$ and sealed. After hydrolysis the tube was opened and the hydrolysate was dried in a vacuum desiccator warmed at $50^{\circ} \mathrm{C}$ and then derivatized with DABS-chloride. ${ }^{7,16)}$ The dried hydrolysate was dissolved in $10 \mu \mathrm{l}$ of $0.1 \mathrm{M}$ sodium bicarbonate buffer ( $\mathrm{pH}$ 9.0 ), and $20 \mu$ l of DABS-C1 solution ( $4 \mathrm{~mm}$ in acetone) was added. The tube was heated at $55^{\circ} \mathrm{C}$ for $20 \mathrm{~min}$ with occasional shaking. After derivatization, the sample was diluted with $10 \mathrm{~mm}$ sodium phosphate buffer ( $\mathrm{pH}$ 6.5) to $100 \mu \mathrm{l}$, and $10 \mu \mathrm{l}$ of the diluted sample was injected for HPLC analysis after centrifugation.

Hydrolysis of DNS amino acids. Ten microliters of a standard amino acid mixture $(500 \mathrm{pmol}$ each) in $0.1 \mathrm{M}$ sodium carbonate buffer ( $\mathrm{pH} 9.0$ ) was mixed with $10 \mu \mathrm{l}$ of DNS-C1 solution $\left(7.4 \mathrm{~mm}\right.$ in acetone) and heated at $50^{\circ} \mathrm{C}$ for $15 \mathrm{~min}$ with occasional shaking. The reaction mixture was vacuum evaporated and treated with $80 \mu \mathrm{l}$ of $6 \mathrm{M} \mathrm{HCl}$ containing phenol at $110^{\circ} \mathrm{C}$ under vacuum. After drying in vacuo, the residue was dissolved in $20 \mu \mathrm{l}$ of $50 \%$ acetone in $10 \mathrm{~mm}$ sodium phosphate buffer $(\mathrm{pH} 7.0)$ and diluted with $80 \mu \mathrm{l}$ of $10 \mathrm{~mm}$ sodium phosphate buffer $(\mathrm{pH} \mathrm{7.0)}$. Ten microliters of the sample was injected for HPLC analysis.

Chromatographic conditions. Chromatography equipment consisted of a Jasco Tri Rotor SR pump, a Jasco Tri Rotor SR 2 controller, and a Jasco Uvidec IV variable wavelength detector at $436 \mathrm{~nm}$ for DABS derivatives or $350 \mathrm{~nm}$ for DNS derivatives. The sensitivity of the detector was set at 0.005 AUFS (absorption unit, full scale). Data were processed by a SIC Chromatocorder 11. A saturator column $(4.6 \times 50 \mathrm{~mm})$ dry-packed with Wakogel LC ODS$30 \mathrm{~K}(30 \mu \mathrm{m}$ particles, Wako Pure Chemicals) and a Hypersil ODS ( $3 \mu \mathrm{m}$ particles, Shadon Southern Products) column $(4.6 \times 100 \mathrm{~mm})$ slurry packed in our laboratory were connected through a valve injector, and were housed within an oven compartment maintained at $60^{\circ} \mathrm{C}$. The elution solvent systems were (A) $10 \mathrm{~mm}$ sodium phosphate buffer, and (B) $10 \mathrm{~mm}$ sodium phosphate buffer-acetone $(50: 50, \mathrm{v} / \mathrm{v})^{8)}$ The $\mathrm{pH}$ of the phosphate buffer was adjusted to 6.5 for the separation of DABS derivatives and 7.0 for DNS derivatives. The flow rate was $1.0 \mathrm{ml} / \mathrm{min}$.

Preparation of CAM-AFT-III. Sea anemone toxins were isolated from Anthopleura fuscoviridis by extraction with methanol, gel filtration on Sephadex G-50, and ionexchange chromatography on SP-Sephadex as previously described. ${ }^{9)}$ The final purification was achieved by reversed-phase HPLC to give three toxins, AFT-1, AFTII, and AFT-III. The yields of these toxins were $55.9 \mathrm{mg} / \mathrm{kg}, 53.7 \mathrm{mg} / \mathrm{kg}$, and $2.1 \mathrm{mg} / \mathrm{kg}$, respectively. In this study, the amino acid sequence of AFT-III was analyzed.

AFT-III was carboxamidomethylated by reduction and alkylation of disulfide bonds by the method of McWherter et al. ${ }^{10)}$ AFT-III $(850 \mu \mathrm{g})$ was dissolved in $150 \mu \mathrm{l}$ of deoxygenated modification buffer $(0.5 \mathrm{M}$ Tris- $\mathrm{HCl}, \mathrm{pH} 8.5$, $6 \mathrm{~m}$ guanidine- $\mathrm{HCl}$, and $2.5 \mathrm{~mm}$ EDTA). One hundred microliters of dithiothreitol solution $(21 \mathrm{mg} / \mathrm{ml}$ in the modification buffer) was added. The reduction took place at room temperature for $1 \mathrm{hr}$. At that time, $5.4 \mathrm{mg}$ of monoiodoacetamide was added and the reaction proceeded for $20 \mathrm{~min}$ in the dark. The reaction mixture was then injected into a TSK ODS 120T $(10 \mu \mathrm{m}, 4.6 \times 50 \mathrm{~mm}$, Toyo Soda) column equilibrated with $0.1 \%$ trifluoroacetic acid (TFA). The column was eluted with $0.1 \%$ TFA and then with $80 \%$ acetonitrile in $0.1 \%$ TFA. S-Carboxamidomethylated (CAM) AFT-III detected by monitoring the absorbance at $280 \mathrm{~nm}$ was collected and lyophilized to yield $380 \mu \mathrm{g}$.

Enzymatic digestion of CAM-AFT-III. CAM-AFT-III $(150 \mu \mathrm{g})$ was digested with TPCK-trypsin (Worthington) (substrate/enzyme $=100: 1, \mathrm{w} / \mathrm{w}$ ) in $0.2 \mathrm{ml}$ of $0.1 \mathrm{M}$ $\mathrm{NH}_{4} \mathrm{HCO}_{3}(\mathrm{pH} 8.0)$ at $38^{\circ} \mathrm{C}$ for $16 \mathrm{hr}$. Fifty micrograms of CAM-AFT-III was digested with chymotrypsin (P-L Biochemicals) $(100: 1, \mathrm{w} / \mathrm{w})$ in $100 \mu \mathrm{l}$ of $0.1 \mathrm{M} \mathrm{NH}_{4} \mathrm{HCO}_{3}$ at $38^{\circ} \mathrm{C}$ for $6 \mathrm{hr}$. The digests were purified by reversedphase HPLC on a TSK ODS 120T column $(10 \mu \mathrm{m}$, $4.6 \times 250 \mathrm{~mm}$ ) equilibrated with $0.1 \%$ TFA. The column was eluted with a linear gradient of acetonitrile at a flow rate of $1.0 \mathrm{ml} / \mathrm{min}$.

Amino acid analysis. One tenth to $1 / 20$ of each fraction was taken in a hydrolysis tube and dried under a vacuum. Peptides were hydrolyzed in vacuo with $80 \mu \mathrm{l}$ of $6 \mathrm{M} \mathrm{HCl}$ containing phenol for $22 \mathrm{hr}$ at $110^{\circ} \mathrm{C}$. The hydrolysates were analyzed by the DABS-C1 method as described above.

Amino acid sequence analysis. The amino acid sequences of CAM-AFT-III and peptides obtained by enzymic digestion were determined by the manual fluorescein isothiocyanate (FITC) method. ${ }^{11,12)}$ The resulting fluoresceinthiohydantoin (FTH) amino acid was identified by reversed-phase HPLC using a Hypersil ODS $(3 \mu \mathrm{m}$, $4.6 \times 50 \mathrm{~mm}$ ) column. ${ }^{13)}$ 


\section{RESULTS}

A standard amino acid mixture $(250 \mathrm{pmol})$ was treated with various volumes of $6 \mathrm{M} \mathrm{HCl}$ in the presence and absence of phenol at $110^{\circ} \mathrm{C}$ for $22 \mathrm{hr}$ and recovey was determined (Table I). No tryptophan was recovered in the absence of phenol. By the addition of phenol to $6 \mathrm{M}$ $\mathrm{HCl}$, tryptophan was recovered, and the recovery increased by increasing the volume of $6 \mathrm{M} \mathrm{HCl}$ containing phenol. The maximum recovery $(85 \%)$ for tryptophan was obtained by $80 \mu \mathrm{l}$ of $6 \mathrm{M} \mathrm{HCl}$ containing $0.7 \%$ phenol. However, $6 \mathrm{M} \mathrm{HCl}$ containing phenol gave a lower recovery of cystine and histidine than when $6 \mathrm{M} \mathrm{HCl}$ alone was used. The recovery of tryptophan was also dependent on the concentration of phenol in $6 \mathrm{M} \mathrm{HCl}$ as shown in Fig. 1 . When a lower concentration $(0.35 \%)$ of phenol was used in the hydrolysis, the recovery was about $30 \%$. On the other hand, increasing the concentration of phenol above $0.7 \%$ did not raise the recovery above $85 \%$.

Figure 2 shows the HPLC chromatogram of DABS derivatives of standard amino acids.
Tryptophan eluted between leucine and phenylalanine. For reference, the chromatogram of a blank sample is presented in the lower panel. The blank sample represents the backgrounds that were derived from a hydrolysis tube, $6 \mathrm{M}$ $\mathrm{HCl}$ containing phenol, and derivatizing reagents. No significant background peak which

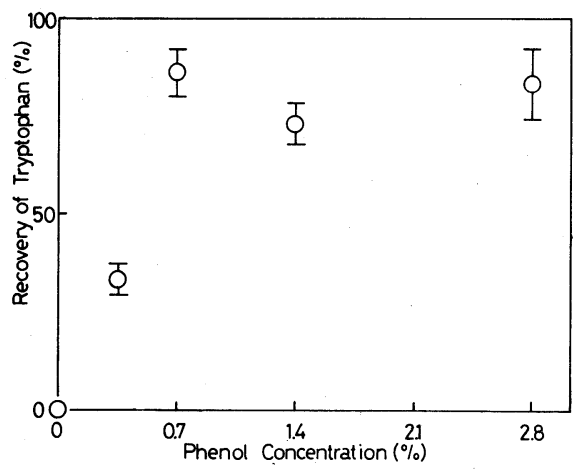

FIG. 1. Effects of the Concentration of Phenol on the Recovery of Tryptophan.

An amino acid mixture $(250 \mathrm{pmol})$ was treated with $80 \mu \mathrm{l}$ of $6 \mathrm{M} \mathrm{HCl}$ containing various concentration of phenol at $110^{\circ} \mathrm{C}$ for $22 \mathrm{hr}$. The recovery of tryptophan was measured by HPLC as described in the text. $\%$ Mean values ( \pm S.E.) of six dependent experiments were plotted.

Table I. Effects of the Volume of $6 \mathrm{M} \mathrm{HCl} \mathrm{on} \mathrm{the} \mathrm{Recovery} \mathrm{of} \mathrm{Amino} \mathrm{Acids}$ by Hydrolysis with $6 \mathrm{~m} \mathrm{HCl} \mathrm{in} \mathrm{the} \mathrm{Presence} \mathrm{and} \mathrm{Absence} \mathrm{of} \mathrm{Phenol}$

\begin{tabular}{|c|c|c|c|c|c|c|c|c|}
\hline & \multicolumn{4}{|c|}{$6 \mathrm{M} \mathrm{HCl}$} & \multicolumn{4}{|c|}{$6 \mathrm{M} \mathrm{HCl}$ containing $0.7 \%$ phenol } \\
\hline & $10 \mu \mathrm{l}$ & $20 \mu \mathrm{l}$ & $40 \mu \mathrm{l}$ & $80 \mu \mathrm{l}$ & $10 \mu \mathrm{l}$ & $20 \mu \mathrm{l}$ & $40 \mu \mathrm{l}$ & $80 \mu \mathrm{l}$ \\
\hline Asp & $91 \pm 9$ & $94 \pm 1$ & $80 \pm 12$ & $101 \pm 1$ & $95 \pm 13$ & $97 \pm 0$ & $92 \pm 5$ & $90 \pm 2$ \\
\hline Glu & $117 \pm 11$ & $99 \pm 4$ & $109 \pm 5$ & $119 \pm 6$ & $109 \pm 6$ & $114 \pm 6$ & $111 \pm 1$ & $111 \pm 7$ \\
\hline Ser & $111 \pm 3$ & $105 \pm 5$ & $104 \pm 6$ & $98 \pm 2$ & $99 \pm 3$ & $104 \pm 3$ & $105 \pm 4$ & $93 \pm 2$ \\
\hline Thr & $102 \pm 5$ & $100 \pm 6$ & $99 \pm 4$ & $92 \pm 3$ & $94 \pm 1$ & $105 \pm 11$ & $100 \pm 4$ & $88 \pm 1$ \\
\hline Gly & $133 \pm 12$ & $109 \pm 10$ & $119 \pm 4$ & $120 \pm 3$ & $104 \pm 5$ & $125 \pm 12$ & $113 \pm 1$ & $104 \pm 1$ \\
\hline Ala & $106 \pm 4$ & $104 \pm 7$ & $101 \pm 1$ & $104 \pm 2$ & $100 \pm 6$ & $115 \pm 15$ & $110 \pm 5$ & $103 \pm 2$ \\
\hline Pro & $108 \pm 5$ & $106 \pm 6$ & $105 \pm 4$ & $103 \pm 2$ & $97 \pm 3$ & $105 \pm 6$ & $103 \pm 4$ & $99 \pm 3$ \\
\hline Val & $102 \pm 0$ & $96 \pm 3$ & $103 \pm 3$ & $98 \pm 4$ & $100 \pm 2$ & $107 \pm 7$ & $104 \pm 3$ & $100 \pm 3$ \\
\hline Arg & $98 \pm 1$ & $97 \pm 2$ & $104 \pm 6$ & $103 \pm 5$ & $104 \pm 3$ & $103 \pm 0$ & $109 \pm 1$ & $102 \pm 3$ \\
\hline Met & $110 \pm 2$ & $112 \pm 4$ & $109 \pm 8$ & $78 \pm 5$ & $96 \pm 1$ & $108 \pm 5$ & $108 \pm 5$ & $92 \pm 5$ \\
\hline Ile & $104 \pm 4$ & $94 \pm 4$ & $96 \pm 1$ & $92 \pm 4$ & $94 \pm 0$ & $103 \pm 3$ & $103 \pm 1$ & $99 \pm 2$ \\
\hline Leu & $114 \pm 6$ & $101 \pm 6$ & $100 \pm 3$ & $101 \pm 5$ & $97 \pm 1$ & $106 \pm 4$ & $107 \pm 1$ & $102 \pm 2$ \\
\hline Trp & 0 & 0 & 0 & 0 & $27 \pm 7$ & $44 \pm 11$ & $78 \pm 2$ & $85 \pm 2$ \\
\hline Phe & $95 \pm 2$ & $99 \pm 8$ & $96 \pm 2$ & $93 \pm 3$ & $94 \pm 1$ & $102 \pm 5$ & $105 \pm 3$ & $99 \pm 2$ \\
\hline$(\mathrm{Cys})_{2}$ & $75 \pm 1$ & $78 \pm 6$ & $66 \pm 2$ & $53 \pm 5$ & $67 \pm 5$ & $46 \pm 5$ & $32 \pm 5$ & $21 \pm 3$ \\
\hline Lys & $69 \pm 9$ & $86 \pm 19$ & $73 \pm 2$ & $85 \pm 12$ & $89 \pm 3$ & $78 \pm 19$ & $81 \pm 11$ & $84 \pm 5$ \\
\hline His & $43 \pm 5$ & $61 \pm 12$ & $42 \pm 12$ & $82 \pm 12$ & $59 \pm 9$ & $60 \pm 20$ & $62 \pm 12$ & $56 \pm 4$ \\
\hline Tyr & $65 \pm 1$ & $73 \pm 22$ & $72 \pm 22$ & $83 \pm 8$ & $101 \pm 5$ & $110 \pm 13$ & $112 \pm 13$ & $105 \pm 3$ \\
\hline
\end{tabular}

$\%$ Mean values of three experiments. \pm S.E. 
Table II. Amino Acid Compositions of CAM-AFT-III And Lysozyme Hydrolyzed with $6 \mathrm{~m} \mathrm{HCl}$ Containing Phenol

\begin{tabular}{|c|c|c|c|c|c|c|}
\hline & \multicolumn{2}{|c|}{ AFT-III } & \multicolumn{4}{|c|}{ Lysozyme } \\
\hline & \multirow{2}{*}{$\begin{array}{l}\text { Expected } \\
\text { values }\end{array}$} & \multirow{2}{*}{$\begin{array}{c}\text { Experimental } \\
\text { results } \\
\text { I }\end{array}$} & \multirow{2}{*}{$\begin{array}{l}\text { Expected } \\
\text { values }\end{array}$} & \multicolumn{3}{|c|}{$\begin{array}{l}\text { Experimental } \\
\text { results }\end{array}$} \\
\hline & & & & I & II & III \\
\hline Asp & 4 & 4.2 & 21 & 20.9 & 20.8 & 19.7 \\
\hline Glu & 1 & 1.4 & 5 & 5.5 & 6.3 & 5.9 \\
\hline Cys & 6 & $4.4^{a}$ & 8 & 0.8 & 0.4 & 0.6 \\
\hline Ser & 4 & 3.2 & 10 & 9.0 & 9.2 & 8.7 \\
\hline Thr & 2 & 1.9 & 7 & 6.5 & 6.8 & 6.9 \\
\hline Gly & 9 & 9.0 & 12 & 11.4 & 11.4 & 10.4 \\
\hline Ala & 2 & 2.3 & 12 & 12.0 & 12.0 & 12.0 \\
\hline Pro & 4 & 4.3 & 2 & 2.5 & 2.5 & 2.3 \\
\hline Val & 2 & 2.1 & 6 & 6.5 & 6.5 & 6.3 \\
\hline Arg & 1 & 1.1 & 11 & 12.3 & 12.3 & 12.2 \\
\hline Met & 0 & 0 & 2 & 2.2 & 2.1 & 2.3 \\
\hline Ile & 3 & 2.4 & 6 & 6.0 & 6.2 & 6.1 \\
\hline Leu & 3 & 3.4 & 8 & 8.8 & 9.1 & 8.9 \\
\hline Trp & 3 & 2.5 & 6 & 4.1 & 3.7 & 4.4 \\
\hline Phe & 0 & 0 & 3 & 3.6 & 3.8 & 3.6 \\
\hline Lys & 2 & 1.5 & 6 & 6.8 & 6.9 & 6.8 \\
\hline His & 2 & 1.0 & 1 & 1.4 & 1.5 & 1.3 \\
\hline Tyr & 0 & 0 & 3 & 3.7 & 3.7 & 3.6 \\
\hline
\end{tabular}

I: Hydrolysis was done in $80 \mu \mathrm{l}$ of $6 \mathrm{M} \mathrm{HCl}$ containing $0.7 \%$ phenol. II: Hydrolysis was done in $160 \mu$ l of $6 \mathrm{M} \mathrm{HCl}$ containing $0.7 \%$ phenol. III: Hydrolysis was done in $80 \mu \mathrm{l}$ of $6 \mathrm{M} \mathrm{HCl}$ containing $2.8 \%$ phenol.

a Measured as $S$-carboxymethylcysteine.

interfered the analysis of DABS amino acids was observed in this experiment.

Table II shows the amino acid compositions of CAM-AFT-III and lysozyme after hydrolysis with $80 \mu \mathrm{l}$ of $6 \mathrm{M} \mathrm{HCl}$ containing phenol for $22 \mathrm{hr}$ at $110^{\circ} \mathrm{C}$. One microgram of sample was hydrolyzed and derivatized with DABS-C1. One tenth of the derivatized sample was enough to give an adequate response in this HPLC system (Fig. 3). Tryptophan was recovered from CAM-AFT-III and lysozyme in a yield of $83 \%$ and $68 \%$, respectively. Neither a larger volume of $6 \mathrm{M} \mathrm{HCl}$ containing $0.7 \%$ phenol nor a higher concentration of phenol in $6 \mathrm{M} \mathrm{HCl}$ improved the recovery of tryptophan from lysozyme. The yield of cystine was very low.

Recovery of tryptophan from acid hydrolysis in the presence of phenol encouraged us to examine the recovery of DNS-tryptophan. As can be seen from Table III, DNS- tryptophan gave recoveries of $40 \%$ and $28 \%$ after hydrolysis for $4 \mathrm{hr}$ and $16 \mathrm{hr}$, respectively. This result indicates that DNS-tryptophan is less stable than free tryptophan in these conditions.

Figure 4 shows the separation of three sea anemone toxins, AFT-I, AFT-II, and AFTIII, on reversed-phase HPLC. AFT-II and AFT-III were separated by the solvent system of $10 \mathrm{~mm}$ ammonium acetate $(\mathrm{pH} \mathrm{6.5)}$ and 2propanol, but not by the solvent system of $0.1 \%$ TFA and acetonitrile. After carboxamidomethylation, AFT-II and AFT-III could not be resolved even with the $10 \mathrm{~mm}$ ammonium acetate ( $\mathrm{pH}$ 6.5)-2-propanol system.

The manual amino terminal sequencing of $5 \mathrm{nmol}$ of CAM-AFT-III yielded the sequence of residues 1 through 17 and showed one potential tryptic cleavage site between 15 and 16. The FITC derivative from the 10 th residue eluted at the position of alanine, but the amino 


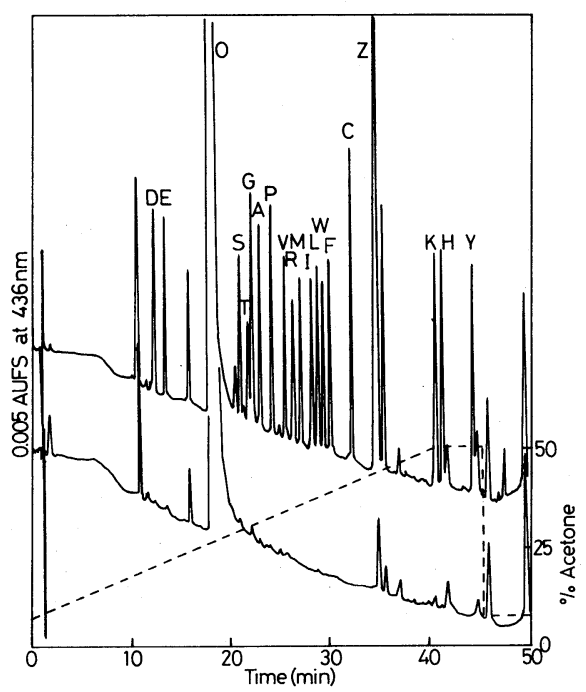

Frg. 2. HPLC Chromatogram of DABS Amino Acids.

An amino acid mixture $(250 \mathrm{pmol})$ was derivatized as described in the text and $10 \mu \mathrm{l}(25 \mathrm{pmol})$ of the derivatized sample was chromatographed. Column: Hypersil ODS $(3 \mu \mathrm{m}), 4.6 \times 100 \mathrm{~mm}$. Gradient elution, mobile phase: $\mathrm{A}=10 \mathrm{~mm}$ phosphate buffer ( $\mathrm{pH} 6.5$ ); $\mathrm{B}=10 \mathrm{~mm}$ phosphate buffer, $\mathrm{pH}$ 6.5-acetone $(50: 50)$, flow-rate $1.0 \mathrm{ml} / \mathrm{min}$. The gradient profile is shown by the broken line. The one-letter code for the amino acids is used except for the following abbreviations: $\mathrm{C}=$ cystine; $\mathrm{O}=$ sulfonic acid; $\mathrm{Z}=$ amide.

acid analysis of the tryptic peptide containing the sequence showed the residue was a derivative of aspartic acid (Fig. 5), and the FITC derivative regenerated $\mathrm{FTH}$-aspartic acid by heating at $50^{\circ} \mathrm{C}$ for $1 \mathrm{hr}$ in $6 \mathrm{M} \mathrm{HCl}$.

In order to determine the amino acid sequence of CAM-AFT-III, the peptide was digested with trypsin and separated by reversed-phase HPLC (Fig. 6). Seven major peptides were isolated and analyzed using the hydrolytic procedure described here. Five of them contained tryptophan (Table IV). Chymotryptic digestion of CAM-AFT-III yielded six major peptides which could be separated and purified by HPLC as shown in Fig. 7. Four of them contained tryptophan (Table V). The sequence of the tryptic and chymotryptic peptides were analyzed by the manual FITC method.

The amino acid sequence of AFT-III is

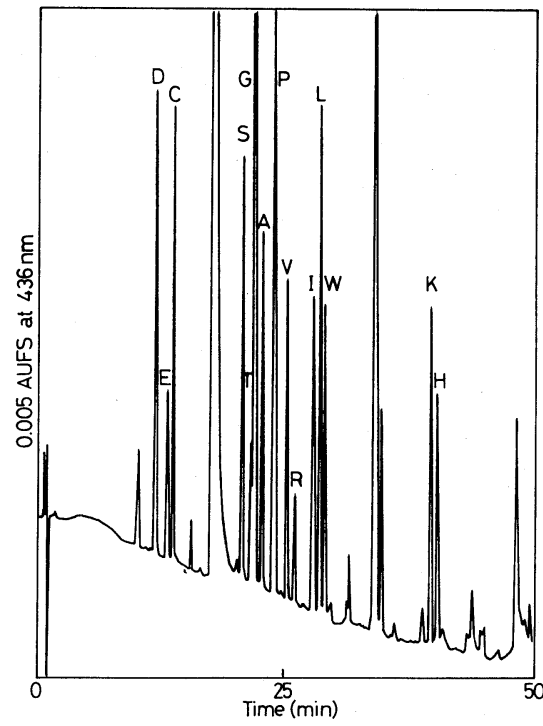

FIG. 3. HPLC Chromatogram of DABS Amino Acids Generated after Hydrolysis and Derivatization of CAMAFT-III.

CAM-AFT-III $(1 \mu \mathrm{g})$ was hydrolyzed with $80 \mu \mathrm{l}$ of $6 \mathrm{M}$ $\mathrm{HCl}$ containing phenol at $110^{\circ} \mathrm{C}$ for $22 \mathrm{hr}$ in vacuo. The hydrolyzate was derivatized with DABS-Cl as described in the text, and one tenth of the sample was injected. Chromatographic conditions were the same as those in Fig. 2. $\mathrm{C}=S$-carboxymethylcysteine.

shown in Fig. 8 together with the details of the peptides from which it was deduced. In most cases, quantitative amino acid analysis using our hydrolytic procedure supported the sequences obtained.

\section{DISCUSSION}

To determine the amino acid sequence of a protein or peptide, the amino acid compositions of many peptide fragments must be analyzed rapidly from small quantities of sample. Thus, micro amino acid analysis using a single hydrolysis is desirable. As examples, Tables IV and V show amino acid compositions of tryptic and chymotryptic peptides obtained from CAM-AFT-III. In general, a single amino acid analysis using the method described here gave acceptable results with a good recovery of tryptophan. Although the addition of phenol to $6 \mathrm{M} \mathrm{HCl}$ is common to 
get a good yield of tyrosine, ${ }^{14)}$ no paper has described the protective effect of phenol for tryptophan. The concentration of phenol used in acid hydrolysis is usually $0.1 \sim 0.2 \%$. Recently, gas-phase hydrolysis using $6 \mathrm{M} \mathrm{HCl}$

TABLE III. RECOVERY OF DNS-Amino ACIDS By Hydrolysis WITH $6 \mathrm{M} \mathrm{HCl} \mathrm{CON-}$ TAINING $0.7 \%$ Phenol

\begin{tabular}{lrr} 
& $4 \mathrm{hr}$ & $16 \mathrm{hr}$ \\
\hline Asp & 109 & 98 \\
Glu & 102 & 89 \\
Ser & 84 & 60 \\
Gly & 111 & 74 \\
Thr & 110 & 90 \\
Ala & 95 & 80 \\
Arg + Pro & 78 & 47 \\
Val & 106 & 97 \\
Met & 93 & 90 \\
Ile & 110 & 90 \\
Leu & 106 & 97 \\
Trp & 40 & 28 \\
Phe & 107 & 97 \\
(Cys) ${ }_{2}$ & 26 & 6 \\
Lys & 97 & 82 \\
His & 9 & 1 \\
Tyr & 109 & 102 \\
\hline
\end{tabular}

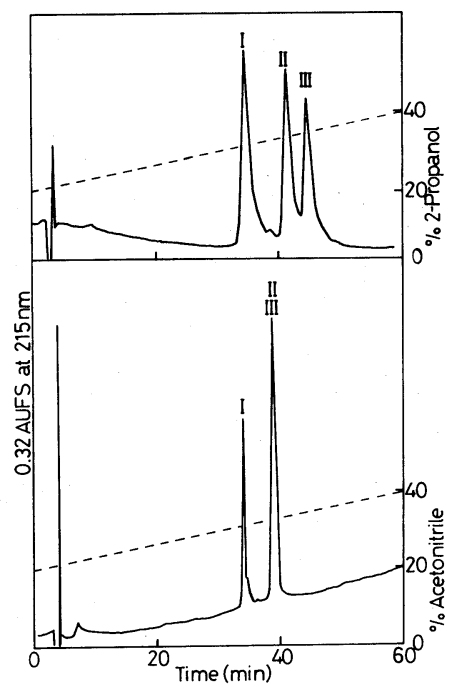

FIG. 4. HPLC Chromatograms of Anemone Toxins.

Column, TSK ODS $120 \mathrm{~T}(10 \mu \mathrm{m}), 4.6 \times 250 \mathrm{~mm}$; flow rate, $1.0 \mathrm{ml} / \mathrm{min}$. In the upper panel, the column was eluted with a linear gradient of 2-propanol-10 $\mathrm{mm}$ ammonium acetate ( $\mathrm{pH}$ 6.5) system and in the lower panel the column was eluted with a linear gradient of acetonitrile- $0.1 \%$ TFA system. Ten micrograms of each peptides was injected. I, AFT-I; II, AFT-II; III, AFT-III.

$\%$ Mean values of two analyses.

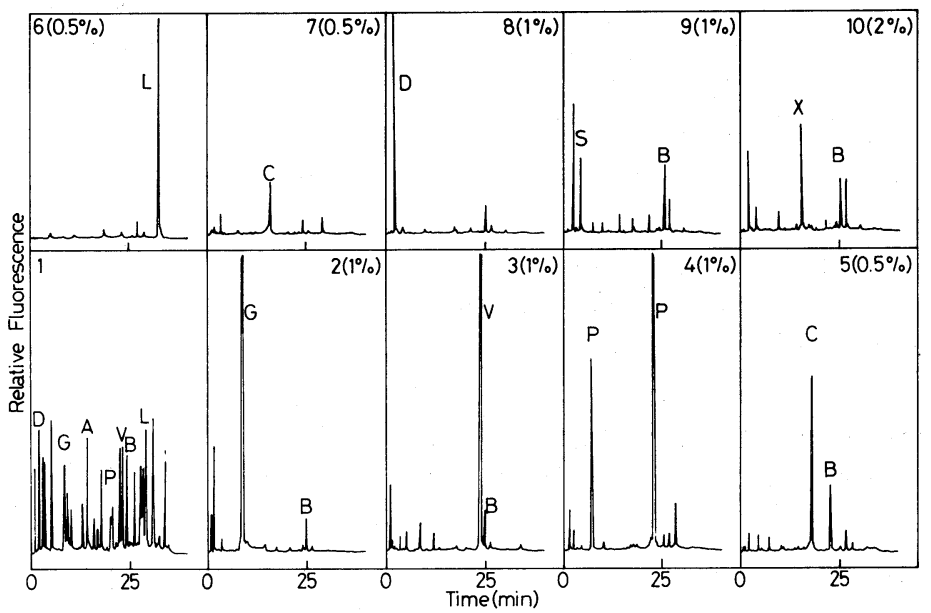

Fig. 5. HPLC Chromatograms from the Sequencing of $5 \mathrm{nmol}$ of CAM-AFT-III.

Column, Hypersil ODS $(3 \mu \mathrm{m}), 4.6 \times 50 \mathrm{~mm}$; column temperature, $60^{\circ} \mathrm{C}$; gradient elution, mobile phase, $\mathrm{A}=10 \mathrm{~mm}$ sodium phosphate buffer ( $\mathrm{pH} 7.0) ; \mathrm{B}=10 \mathrm{~mm}$ sodium phosphate buffer ( $\mathrm{pH} 7.0)$-acetone $(80: 20) ; \mathrm{a}$ 30 min linear gradient from 15 to $70 \%$ solvent B. Panel 1 is a chromatogram of authentic FTH amino acids. The cycle number $(2 \sim 10)$ of each step is given in each chromatogram. Percentages of extracts of FTH amino acids used for HPLC analysis at each cycle are indicated in parentheses. $\mathrm{B}=$ internal marker; $\mathrm{C}=S$ carboxamidomethylcysteine; $\mathrm{X}=$ unknown derivative. 
Table IV. Amino Acid Compositions of Tryptic Peptides Obtained from CAM-AFT-III

\begin{tabular}{|c|c|c|c|c|c|c|c|}
\hline & $\mathrm{T} 1$ & $\mathrm{~T} 2$ & T3 & $\mathrm{T} 4$ & T5 & T6 & $\mathrm{T} 7$ \\
\hline Asp & & $1.0(1)^{a}$ & $2.1(2)$ & & & $1.0(1)$ & $1.8(2)$ \\
\hline \multicolumn{8}{|l|}{ Glu } \\
\hline $\mathrm{Cys}^{b}$ & $1.5(2)$ & $1.4(2)$ & $1.6(2)$ & $1.3(2)$ & & & $1.6(2)$ \\
\hline Ser & & $0.8(1)$ & $1.6(2)$ & & & $0.9(1)$ & $1.5(2)$ \\
\hline Thr & & & & $1.0(1)$ & $0.9(1)$ & $0.9(1)$ & 0.9 (1) \\
\hline Gly & & $1.9(2)$ & $2.4(3)$ & $1.9(2)$ & $1.9(2)$ & $2.0(2)$ & $4.1(4)$ \\
\hline Ala & & $1.0(1)$ & & $0.9(1)$ & $1.1(1)$ & & $1.0(1)$ \\
\hline Pro & & $1.1(1)$ & $2.0(2)$ & $1.0(1)$ & $1.1(1)$ & & $1.1(1)$ \\
\hline Val & & & $1.9(2)$ & & & & \\
\hline Arg & & & $1.0(1)$ & & & & \\
\hline \multicolumn{8}{|l|}{ Met } \\
\hline Ile & & & & $1.0(1)$ & $1.0(1)$ & $1.1(2)$ & $1.2(2)$ \\
\hline Leu & & $0.9(1)$ & $1.0(1)$ & & & $1.2(1)$ & $2.3(2)$ \\
\hline Trp & & $0.7(1)$ & & $0.7(1)$ & 0.9 (1) & $0.8(1)$ & $2.0(2)$ \\
\hline \multicolumn{8}{|l|}{ Phe } \\
\hline Lys & $1.0(1)$ & $0.8(1)$ & & $0.7(1)$ & & & $0.8(1)$ \\
\hline $\mathrm{His}$ & & $0.7(1)$ & & $0.5(1)$ & $0.4(1)$ & & $0.6(1)$ \\
\hline Tyr & & & & & & & \\
\hline
\end{tabular}

a The numbers of parentheses are from the sequence analysis.

b Measured as $S$-carboxymethylcysteine.

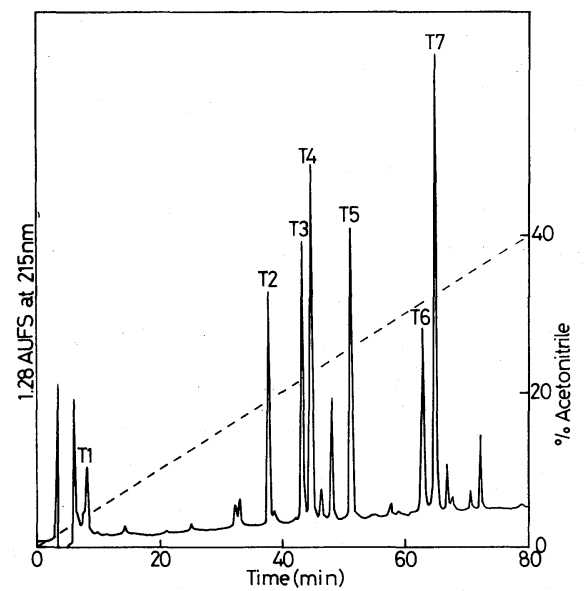

FIG. 6. HPLC Separation of Tryptic Peptides of CAMAFT-III.

Tryptic peptides from the digestion of $150 \mu \mathrm{g}$ of CAMAFT-III were dissolved in $0.1 \%$ TFA, and put on a TSK ODS $120 \mathrm{~T}(10 \mu \mathrm{m}, 4.6 \times 250 \mathrm{~mm})$ column equilibrated with $0.1 \%$ TFA and eluted with a linear gradient of acetonitrile in $0.1 \%$ TFA.

containing $1 \%$ phenol of peptides and proteins has been reported for micro amino acid analysis coupled with precolumn labeling with phenylisothiocyanate. ${ }^{15}$ ) We recovered tryptophan from liquid-phase hydrolysis with dou-

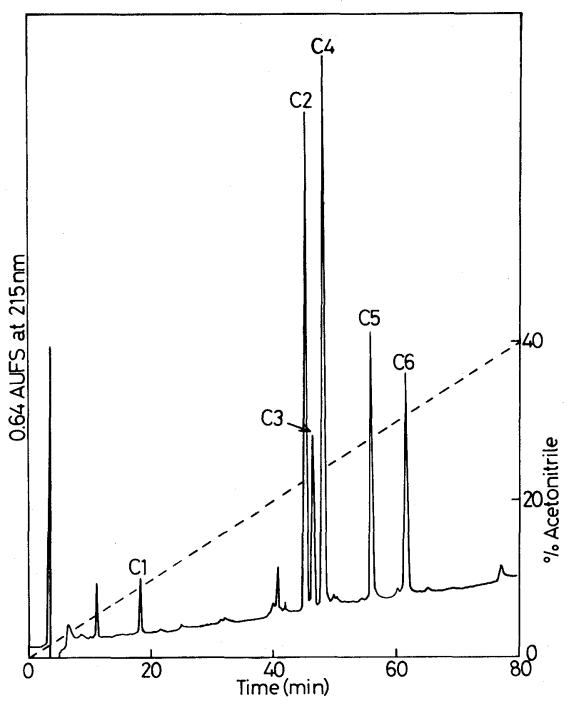

FIG. 7. HPLC Separation of Chymotryptic Peptides of CAM-AFT-III.

Chymotryptic peptides from the digestion of $50 \mu \mathrm{g}$ of CAM-AFT-III were dissolved in $0.1 \%$ TFA, and put on a TSK ODS 120T column as described in Fig. 6.

ble distilled $6 \mathrm{M} \mathrm{HCl}$ containing $1 \%$ phenol. The recovery depended on the volume of the $6 \mathrm{M} \mathrm{HCl}$. Therefore, it is not surprising if tryptophan can not be recovered from gas- 


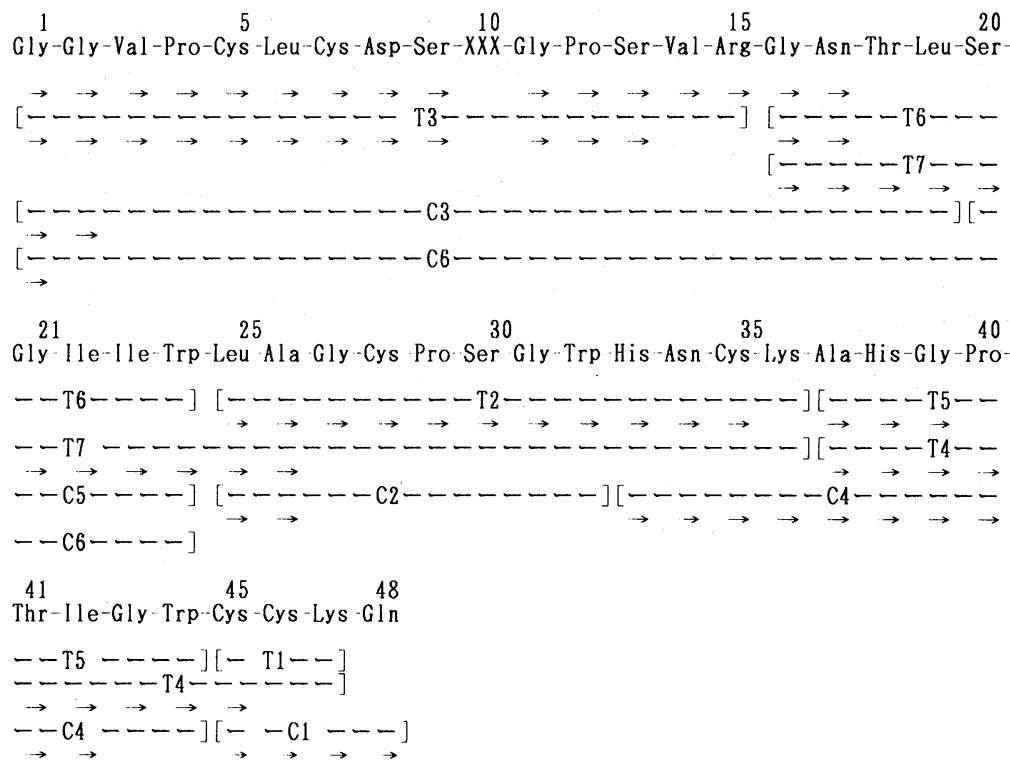

FIG. 8. The Amino Acid Sequence of AFT-III.

The sequence was reconstructed from the data derived with CAM-AFT-III and the tryptic and chymotryptic peptides. Arrows pointing to the right indicate sequences determined by the manual FITC method. T, tryptic peptides; C, chymotryptic peptides.

Table V. Amino Acid Compositions of ChymoTRYPTIC PePtides ObTAined FROM CAM-AFT-III

\begin{tabular}{lcccccc}
\hline & C1 & C2 & C3 & C4 & C5 & C6 \\
\hline Asp & & & $3.0(3)^{a}$ & $1.0(1)$ & & $2.7(3)$ \\
Glu & $1.0(1)$ & & & & & \\
Cys & $1.3(2)$ & $0.8(1)$ & $1.1(2)$ & $0.5(1)$ & & $1.5(2)$ \\
Ser & & $1.0(1)$ & $1.4(2)$ & & $1.0(1)$ & $2.5(3)$ \\
Thr & & & $1.0(1)$ & $1.0(1)$ & & $0.9(1)$ \\
Gly & & $2.0(2)$ & $3.6(4)$ & $2.1(2)$ & $1.5(1)$ & $5.0(5)$ \\
Ala & & $0.9(1)$ & & $1.0(1)$ & & \\
Pro & & $1.1(1)$ & $2.0(2)$ & $1.0(1)$ & & $2.2(2)$ \\
Val & & & $1.9(2)$ & & & $2.0(2)$ \\
Arg & & & $1.0(1)$ & & & $1.1(1)$ \\
Met & & & & & & \\
Ile & & & & $0.9(1)$ & $1.3(2)$ & $1.3(2)$ \\
Leu & & $1.1(1)$ & $2.0(2)$ & & & $2.2(2)$ \\
Trp & & $0.8(1)$ & & $0.6(1)$ & $0.9(1)$ & $0.8(1)$ \\
Phe & & & & & & \\
Lys & $0.7(1)$ & & & $0.8(1)$ & & \\
His & & & & $1.1(2)$ & & \\
Tyr & & & & & & \\
\hline
\end{tabular}

a The numbers of parentheses are from the sequence analysis.

b $\quad$ Measured as $S$-carboxymethylcysteine. phase hydrolysis. The gas-phase hydrolysis has been developed to decrease the background caused by contaminants in $6 \mathrm{M} \mathrm{HCl}$ and to achieve micro amino acid analysis with a high degree of accuracy. Normal liquid-phase hydrolysis consistently results in higher levels of background than gas-phase hydrolysis. ${ }^{16)} \mathrm{We}$ ran a blank sample and examined the background caused by the hydrolytic procedure described here. The blank sample was designated to check the free amino acid, peptide, or protein contaminants that may be present in $6 \mathrm{M} \mathrm{HCl}$, hydrolysis tubes and derivatizing reagents. As can be seen in Fig. 2, the background did not cause trouble in this study, but we have not examined the effects of the background in smaller samples than that described here.

Although good recovery of tryptophan was obtained in the hydrolysis of free amino acids and peptides, the same conditions resulted in large losses of tryptophan when applied to proteins, such as lysozyme. This could be due to the fact that the destruction of tryptophan when in peptide form is different from that 
when it is present as a free amino acid in the hydrolysis mixture. It is also likely that elements that are not removed from the protein during purification catalyze degradation reactions. ${ }^{17)}$ We do not know exactly how phenol prevents the destruction of tryptophan during acid hydrolysis. Phenol may act as a scavenger of the residual oxidizing agent that might be present in the hydrolysis tube.

DNS-C1 is a well characterized fluorogenic reagent for the identification on amino acids, peptides, and proteins. The DNS-C1 meth$\mathrm{od}^{18)}$ is one of the powerful methods for endgroup and sequence analysis of peptides and proteins. The stability of DNS-amino acids to acid hydrolysis has been evaluated. ${ }^{19,20}$ ) The destruction of tryptophan which occurs, even after a short 4-hr period of hydrolysis at $110^{\circ} \mathrm{C}$, represents a limitation of the DNSEdman method for the sequencing of peptides. Although the introduction of $4 \mathrm{M}$ methanesulfonic acid containing $0.2 \% 3$-(2-aminoethyl)indole $^{21)}$ or $3 \mathrm{M}$ mercaptoethane sulfonic $\mathrm{acid}^{22)}$ has made it possible to recover DNStryptophan, the DNS derivative must be recovered by extraction from the hydrolysate after neutralization, and some hydrophilic amino acid derivatives can not be extracted. ${ }^{22)}$ On the other hand, as $6 \mathrm{M} \mathrm{HCl}$ containing phenol is volatile, the hydrolysate can be dried under a vacuum and identified directly. Thus, this hydrolytic procedure can be coupled to the amino terminal and DNS-Edman analyses. The reason for the low recovery of DNS-histidine is not known.

Neurotoxins have been isolated from a variety of sea anemone species and have become useful tools in physiological, pharmacological, and biochemical studies. The amino acid sequences of many of these toxins are known. ${ }^{23}$ 29) We have isolated three cardiotoxic polypeptides from Anthopleura fuscoviridis and determined the amino acid sequences of two major toxins, AFT-I and AFTII. ${ }^{9)}$ AFT-I consists of 47 amino acid residues, while AFT-II consists of 48 amino acid residues. There are four sequence differences between AFT-I and AFT-II: at residue 3 (Ala for Pro), 12 (Arg for Ser), 21 (Thr for Ile), and an additional Gly at the $\mathrm{N}$-terminal position on AFT-II. The yield of AFT-III was less than $5 \%$ of those of the major toxins. AFT-II was the most toxic to mice and showed a minimum lethal dose of $100 \mu \mathrm{g} / \mathrm{kg}$ by intravenous injection. The minimum lethal dose of AFT-I was $300 \mu \mathrm{g} / \mathrm{kg}$ and of AFT-III was $500 \mu \mathrm{g} / \mathrm{kg}$. The toxicities of the three polypeptides to Hemigrapsus sanguineus crabs were similar and were in the range of 100 to $150 \mu \mathrm{g} / \mathrm{kg}$. In this study, we not only determined the amino acid sequence of AFT-III to investigate the structure-function relationship of AFTs but also applied the hydrolytic procedure described here to this analysis to demonstrate its utility in the amino acid sequence analysis of peptides. The result shows that the amino acid sequence of AFT-III is the same as that of AFT-II except for residue 10 . The $\beta$-carboxyl group of aspartic acid-10 in AFT-III is probably modified to be nonionizable. The characteristic mobilities of AFT-II and AFT-III on HPLC by changing the $\mathrm{pH}$ of the solvents can be accounted for by such modification. In addition, the separation between AFT-II and AFT-III may be achieved by the conformational transition of the molecule which occurs concomitant with protonation of the $\beta$ carboxyl group of the aspartic acid, because AFT-II and AFT-III can not be resolved even at $\mathrm{pH} 6.5$ after S-carboxamidomethylation. The lysine-47-glutamine-48 linkage commonly found in sea anemone toxins has been reported to resist tryptic digestion, ${ }^{9,29)}$ but the linkage of AFT-III was readily cleaved. This indicates that the interaction between aspartic acid-10 and the carboxyl-terminal region in the molecule was disrupted by the modification of the $\beta$-carboxyl group. Comparison of the structures and toxicities of AFT-II and AFT-III shows that aspartic acid-10 is not essential but is important for the expression of the toxic properties of the sea anemone toxin. The study of the structure and biological significance of the derivative of aspartic acid-10 is in progress. 


\section{REFERENCES}

1) H. Matsubara and R. M. Sasaki, Biochem. Biophys. Res. Commun., 35, 175 (1969).

2) Y. Yokote, K. M. Arai and K. Akahane, Anal. Biochem., 152, 245 (1986).

3) T.-Y. Liu and Y. H. Chang, J. Biol. Chem., 246, 2842 (1971).

4) R. J. Simpson, M. R. Neuberger and T.-Y. Liu, J. Biol. Chem., 251, 1936 (1976).

5) B. Penke, R. Ferenczi and K. Kovacs, Anal. Biochem., 60, 45 (1974).

6) K. Maeda, J.-J. Scheffler and A. Tsugita, HoppeSeyler's Z. Physiol. Chem., 365, 1183 (1984).

7) J.-Y. Chang, R. Knecht and D. G. Braun, Methods, in Enzymology, 91, 41 (1983).

8) K. Muramoto and H. Kamiya, Bull. Japan. Soc. Sci. Fish., 51, 817 (1985).

9) S. Sunahara, K. Muramoto, K. Tenma and $\mathrm{H}$. Kamiya. Toxicon, 25, 211 (1987).

10) C. A. McWherter, T. W. Thannhauser, R. A. Fredrickson, M. T. Zagotta and H. A. Scheraga, Anal. Biochem., 141, 523 (1984).

11) K. Muramoto, H. Kawauchi and K. Tuzimura, Agric. Biol. Chem., 42, 1559 (1978).

12) K. Muramoto and H. Kamiya, Biochim. Biophys. Acta, 874, 285 (1986).

13) K. Muramoto, H. Kamiya and H. Kawauchi, Anal. Biochem., 141, 446 (1984).
14) F. Sanger and E. O. P. Thompson, Biochim. Biophys. Acta, 71, 471 (1963).

15) B. A. Bidlingmeyer, S. A. Cohen and T. L. Tarvin, J. Chromatogr., 336, 93 (1984).

16) R. Knecht and J.-Y. Chang, Anal. Chem., 58, 2375 (1986).

17) A. S. Inglis, Methods in Enzymology, 91, 26 (1983).

18) W. R. Gray, Methods in Enzymology, 25, 333 (1972).

19) C. Gros and B. Labouesse, Eur. J. Biochem., 7, 463 (1969).

20) B. S. Hartley, Biochem. J., 119, 805 (1970).

21) R. Flengsrud, Anal. Biochem., 76, 547 (1976).

22) J. R. Giglio, Anal. Biochem., 82, 262 (1977).

23) G. Wunderer, H. Fritz, E. Wachter and W. Machleidt, Eur. J. Biochem., 68, 193 (1976).

24) M. Tanaka, M. Haniu, K. T. Yasunobu and T. R. Norton, Biochemistry, 16, 204 (1977).

25) G. Wunderer and M. Eulitz, Eur. J. Biochem., 89, 11 (1978).

26) T. R. Norton, Fed. Proc., 40, 21 (1981).

27) H. Schweitz, J.-N. Bidard, C. Frelin, D. Pauron, H. P. M. Vijverberg, D. M. Mahasneh, M. Lazdunski, F. Vilbois and A. Tsugita, Biochemistry, 24, 3554 (1985).

28) S. Nishida, S. Fujita, M. Satake and N. Tamiya, Eur. J. Biochem., 150, 171 (1985).

29) N. S. Reimer, C. L. Yasunobu, K. T. Yasunobu and T. R. Norton, J. Biol. Chem., 260, 8690 (1985). 